\title{
A new curcumin analog, CCA-1.1, induces cell death and cell cycle arrest in WiDr colon cancer cells via ROS generation
}

\author{
Febri Wulandari ${ }^{1}$ (D), Muthi Ikawati ${ }^{1,2}$, Mitsunori Kirihata ${ }^{3}$, Jun-Ya Kato ${ }^{4}$, Edy Meiyanto ${ }^{1,2^{*}}$ \\ ${ }^{1}$ Cancer Chemoprevention Research Center, Faculty of Pharmacy, Universitas Gadjah Mada, Yogyakarta, Indonesia. \\ ${ }^{2}$ Macromolecular Engineering Laboratory, Department of Pharmaceutical Chemistry, Faculty of Pharmacy, Universitas Gadjah Mada, Yogyakarta, Indonesia. \\ ${ }^{3}$ Research Center for Boron Neutron Capture Therapy, Osaka Prefecture University, Sakai, Osaka, Japan. \\ ${ }^{4}$ Laboratory of Tumor Cell Biology, Division of Biological Science, Graduate School of Science and Technology, Nara Institute of Science and Technology, \\ Nara, Japan.
}

\begin{tabular}{l}
\hline ARTICLE INFO \\
\hline Received on: 03/06/2021 \\
Accepted on: $14 / 07 / 2021$ \\
Available online: 03/10/2021
\end{tabular}

Key words:

CCA-1.1, colon cancer, cytotoxic, cell cycle, apoptosis, ROS.

\begin{abstract}
The new Pentagamavunone-1 (PGV-1) derivative, chemoprevention-curcumin analog 1.1 (CCA-1.1), is described as an improved physicochemical feature with similar cytotoxic activity on colon cancer cells and binding interaction to various cancer biomarkers. The current study explored the cytotoxic activity related to its ability to promote physiological changes in the WiDr colon cancer cell line. The 3-(4,5-dimethylthiazol-2-yl)-2,5-diphenyltetrazolium bromide assay was used to assess the cell viability of WiDr and NIH-3T3 cells on the treatment of CCA-1.1 and PGV-1. 2',7'-dichlorofluorescein diacetate staining, propidium iodide staining, and annexin V-PI staining were conducted to examine reactive oxygen species (ROS) level, cell cycle profiles, and apoptosis, respectively. For more examination on morphological changes, the SA- $\beta$-gal staining was used to detect senescence occurrence. We retrieved a more significant cytotoxic effect on WiDr by CCA-1.1 than PGV-1 and no effect on NIH-3T3 fibroblast cells. Our compound stimulated the arrest of the cell cycle at the G2/M phase, apoptosis, ROS generation, and senescence at an equal level to PGV-1. Altogether, these data reinforce CCA-1.1 as a viable alternative to PGV-1, attributed to its improved physicochemical features that are beneficial in designing dosage formulations for medical purposes.
\end{abstract}

\section{INTRODUCTION}

Chemoprevention-curcumin analog 1.1 (CCA-1.1) or 2,5-bis-(4-hydroxy-3,5-dimethyl benzylidene)-cyclopentanol (Fig. 1) is a new Pentagamavunone-1 (PGV-1) analog synthesized by Utomo et al. (2021) to construct a more compelling candidate for an anticancer drug. Recently, we reported CCA-1.1 potency on colon cancer through a bioinformatic exploration (Wulandari et al., 2020) and its effect against MCF-7 and T47D breast cancer cells (Novitasari et al., 2021; Wulandari et al., 2021a, 2021b). CCA-1.1 showed a better cytotoxic effect than PGV-1 on WiDr colon cancer cells (Utomo et al., 2021). Considering that CCA-1.1 has a similar structure backbone to PGV-1, it might

"Corresponding Author

Edy Meiyanto, Macromolecular Engineering Laboratory, Department of Pharmaceutical Chemistry, Faculty of Pharmacy, Universitas Gadjah Mada, Yogyakarta, Indonesia.E-mail: edy-meiyanto@ugm.ac.id<smiles>Cc1cc(C=C2CCC(=Cc3cc(C)c(O)c(C)c3)C2=O)cc(C)c1O</smiles>

(A)

(B)

Figure 1. Structure of PGV-1 (A) and CCA-1.1 (B).

have a comparable or more outstanding anticancer activity. The superiority of PGV-1 revealed a remarkable cytotoxic effect on colon cancer cells beyond many recommended drugs for treating colon cancer such as 5-fluorouracil, cisplatin, and doxorubicin (Meiyanto et al., 2018; Wulandari et al., 2018). More specifically, the antiproliferative activity of PGV-1 is related to a unique G2/M cell cycle arrest, apoptosis, senescence induction, reactive oxygen species (ROS) accumulation (Hermawan et al., 2011; Lestari et al., 2019; Meiyanto et al., 2014, 2018, 2019), and inhibition of nuclear 
factor kappa B, resulting in the suppression of cyclooxygenase-2 (COX-2) expression in WiDr colon cancer cells (Meiyanto et al., 2018). Conversely, PGV-1's limitation on physicochemical property obstructs its superiority as an anticancer candidate, and CCA-1.1 might be in place of PGV-1 to be promoted as a more effective anticolon cancer agent.

Developing colon cancer's chemotherapeutic agents with specific targets and fewer side effects remains a serious issue, which is still a crucial concern in cancer research (Ferlay et al., 2019) even though many attempts in recent years have been achieved to improve the outcome quality of patients (Aiello et al., 2019). An appropriate lifestyle might support patients to live longer with an improved quality of life (Aiello et al., 2019). 5-Fluorouracil (5-FU) is the first-line drug to treat colon cancer, which is usually combined with several agents as leucovorin, irinotecan, oxaliplatin, and levoleucovorin (Goto et al., 2019). Many clinicians also applied the combination of 5-FU and different targeted drugs, including bevacizumab, cetuximab, and panitumumab, to increase its efficacy ( $\mathrm{Li}$ et al., 2011). For this concern, surgery is not the best option for colon cancer, but new therapies are still inadequate to manage cancer progression. Moreover, severe various side effects caused by several conventional drugs, such as bone marrow suppression, cardiotoxicity, and gastrointestinal toxicities, often shorten life expectancy in patients (Alessandrino et al., 2019). Developing a harmless drug without resistance is such a substantial issue for colon cancer treatment. $\mathrm{PGV}-1$ is a possible choice for this purpose according to its safety, but CCA-1.1 may be a superior alternative.

We utilized the WiDr cell line as the representation of colon cancer, which is featured by p53 mutation, positive COX2 expression, and excessive ROS accumulation (Meiyanto et al., 2018). This cell line contained p21 and correlated with several drug resistance phenomena, such as cisplatin, 5-FU, and paclitaxel (Handayani et al., 2017; Meiyanto et al., 2018), making it suitable as a model for examining a candidate of a specific anticancer agent. The current study is dedicated to observing cell cycle arrest modulation, ROS generation, apoptosis, and senescence occurrence from CCA1.1's antiproliferative effect. These results would provide supporting data for developing CCA-1.1 as a potent candidate for chemotherapy.

\section{MATERIALS AND METHODS}

\section{Chemical compounds}

CCA-1.1 and PGV-1 were synthesized by Utomo et al. (2021). Doxorubicin was purchased from Sigma-Aldrich.

\section{Cell line and culture conditions}

The fibroblast NIH-3T3 cells cultured in a high glucose Dulbecco's Modified Eagle Medium were contributed by Prof. Masashi Kawaichi, MD. Ph.D., Laboratory of Gene Function in Animals, NAIST, Japan. The colon cancer cells (WiDr) were acquired from the Faculty of Medicine, UGM, Indonesia, and grown in a Roswell Park Memorial Institute 1640 (RPMI-1640) medium. We added 4-(2-hydroxyethyl)-1-piperazineethanesulfonic acid (HEPES) (Sigma), sodium bicarbonate (Sigma), streptomycin 150 $\mu \mathrm{g} / \mathrm{ml}$ and penicillin $150 \mathrm{IU} / \mathrm{ml}$ (Sigma), and $10 \% \mathrm{v} / \mathrm{v}$ fetal bovine serum (FBS) (Sigma) for complementing the culture medium.

\section{3-(4,5-dimethylthiazol-2-yl)-2,5-diphenyltetrazolium bromide (MTT) assay}

To assess cell viability, we utilized an MTT assay. The cells $\left(10^{4}\right.$ cells/well $)$ in 96-well plates were incubated for 24 hours with CCA-1.1 and PGV-1 at varying doses. The medium culture was replaced with an MTT reagent (Sigma). After 4 hours incubation, $100 \mu \mathrm{l}$ of $10 \%$ sodium dodecyl sulphate (SDS) in $0.01 \mathrm{M}$ was added and incubated for 24 hours at room temperature, avoiding light exposure. The next day, we measured the absorbance using a microplate reader at $595 \mathrm{~nm}$ (BioRad).

\section{Evaluation of cell cycle profile}

Propidium iodide staining was used to assess the cell cycle profiles of WiDr cells $\left(2 \times 10^{5}\right.$ cells/well in 6 -well plates $)$ caused by compound treatment. The cell pellets were then collected and processed as a further step as mentioned in the BD Cycletest $^{\mathrm{TM}}$ Plus DNA Kit instruction, following measurement using the flow cytometer BD Bioscience C6.

\section{Staining for apoptosis detection}

Authors conducted annexin $\mathrm{V}$ - propidium iodide (PI) staining-based flow cytometry to examine apoptosis incidence in WiDr cells. The treatment design used is similar to the cell cycle assay. The pellet cells were collected, following cell staining according to the Annexin V-FLUOS Staining Kit (Roche). The stained suspension cells were analyzed by a flow cytometer.

\section{SA- $\beta$-galactosidase assay}

Compounds at concentrations 2 and $4 \mu \mathrm{M}$ were added to cultured $2 \times 10^{5} \mathrm{WiDr}$ cells/well for 24 hours. The next day, cells were washed using phosphate-buffered saline (PBS) and fixed in 4\% paraformaldehyde (Sigma). The cells were rewashed in PBS, following adding a staining solution, and placed for incubation at $37^{\circ} \mathrm{C}$. Senescence cells were observed after 48 hour incubation and indicated as a green color under a light microscope (CKX-41 Olympus) (400× magnification).

\section{ROS level measurement}

Cultured $5 \times 10^{4} \mathrm{WiDr}$ cells/well in a 24-well plate were collected in $500 \mu \mathrm{l}$ PBS containing FBS 10\%, followed by 30 minutes staining with $2^{\prime}, 7^{\prime}$-dichlorofluorescein diacetate (DCFDA) (Sigma) $25 \mathrm{mM}$ (incubation at $37^{\circ} \mathrm{C}, 5 \% \mathrm{CO}_{2}$ atmosphere). Following the staining incubation, cell suspension was added with samples and doxorubicin (4 hours) at selected concentrations. We utilized the BD Accuri C6 ${ }^{\mathrm{TM}}$ Flow Cytometer (BD Bioscience) to analyze \% fluorescein (ROS level) from 20,000 cells.

\section{RESULTS}

\section{Cytotoxic activity}

In the preliminary investigation, $\mathrm{PGV}-1$ displayed an excellent cytotoxic effect compared to 5-FU on WiDr colon cancer cells (Meiyanto et al., 2018). Currently, we confirm that CCA1.1 performed greatly in a dose-dependent phenomenon to treat cancer cells compared with PGV-1 against WiDr cells. CCA-1.1 was a stronger cytotoxic agent than PGV-1 ( $p<0.01)$ (Fig. 2), in which PGV-1 and CCA-1.1 at a concentration of $10 \mu \mathrm{M}$ inhibited cell growth of $47 \%$ and $73.5 \%$, respectively. Both compounds showed no growth inhibitory effect $(<5 \%)$ toward NIH-3T3 cells, 
(A) NIH-3T3

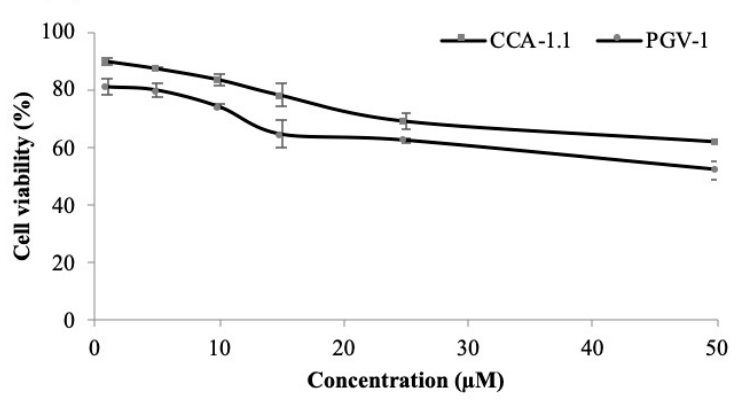

(B) WiDr

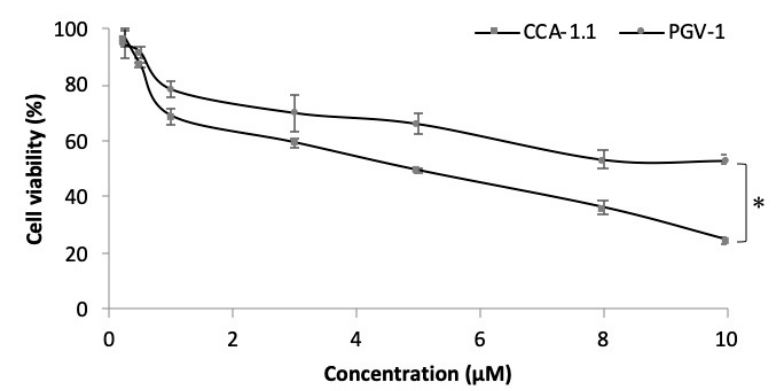

(C)

\begin{tabular}{ccc}
\hline \multirow{2}{*}{ Cell lines } & \multicolumn{2}{c}{ IC $_{\mathbf{5 0}}(\boldsymbol{\mu M})$} \\
\cline { 2 - 3 } & CCA-1.1 & PGV-1 \\
\hline NIH-3T3 & $>50$ & $>50$ \\
\hline WiDr & 5.4 & $>10$ \\
\hline
\end{tabular}

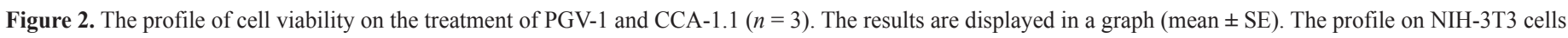
(A) and WiDr cells (B). The quantification of $\mathrm{IC}_{50}(\mu \mathrm{M})$ was presented in a table (C). Statistical analysis was conducted using Student's $t$-test $(* p<0.01)$.

a model of a noncancerous cell (Ahlina et al., 2020). From this result, we suggest that CCA-1.1 can possibly combat PGV-1 as an anticancer candidate, owing to the higher cytotoxic effect on WiDr cells and less toxicity on NIH-3T3 cells.

\section{Cell cycle profile}

As PGV-1 had a specific cytotoxic property against several cancer cells, we believe that CCA-1.1 would imitate its cytotoxicity. PGV-1 was shown to interrupt cell cycle progression causing arrest at the G2/M phase in WiDr cells (Meiyanto et al., 2014). Here, we figure out that both compounds showed similar characteristics in a cell cycle process interruption. CCA-1.1 and PGV-1 increased cell accumulation at the G2/M phase as shown in the green peak in the flow cytogram (Fig. 3) to a wider area over doxorubicin 100 $\mathrm{nM}$, a chemotherapeutic drug as a positive control that triggers G2/M cell cycle arrest in cancer cells (Meiyanto et al., 2020; Thorn et al., 2011). We also spotted an accumulation at the sub-G1 phase in the treatment of CCA-1.1 (2 and $4 \mu \mathrm{M})$ probably representing an apoptosis incidence. We assumed that CCA-1.1 stimulates cell cycle arrest that may subsequently trigger apoptosis.

\section{Apoptosis occurrence}

We then conducted annexin V-PI staining based on a flow cytometry assay to confirm whether sub-G1 arrest caused by CCA-1.1 is indirect cell apoptosis. Apoptosis incidence mainly associates with irreversible cell cycle arrest (Foster, 2008). As the core compound of CCA-1.1, PGV-1 causes increasing apoptosis occurrence in breast cancer (MCF-7 and T47D) and colon cancer cells (WiDr) (Hermawan et al., 2011). We confirmed that CCA1.1 ( 2 and $4 \mu \mathrm{M}, 24$ hours) effectually stimulates apoptosis in WiDr cells, as did PGV-1 at a similar level (Fig. 4). Considering PGV-1, which established induced cell cycle arrest accompanied by apoptosis, senescence, and ROS generation (Lestari et al., 2019; Meiyanto et al., 2019), CCA-1.1 may have an identical spectrum of activity in suppressing cancer cells. However, further investigation is required.

\section{Cellular senescence incidence}

To elucidate the correlation of cell cycle arrest and cellular senescence in the treatment of CCA-1.1, we employed Senescence-Associated (SA)- $\beta$-galactosidase assay and employed doxorubicin to trigger senescence in cells (as a positive control) (Kuilman et al., 2010; Yang et al., 2012). We demonstrated that both doses of CCA-1.1 and PGV-1 cause cellular senescence in WiDr cells $(p<0.001)$ at an equal level with doxorubicin (Fig. 5). We assumed that cellular senescence could be intrinsically related to cell cycle arrest.

\section{Intracellular ROS level}

The level of intracellular ROS plays a crucial role in senescence occurrence (Panieri and Santoro, 2016), also closely associated with the principle of the metabolic process (Davalli et al., 2016) and various implications of cellular stress resulting from physiological maintenance of ROS metabolic enzymes in cancer cells (Kashyap et al., 2019). Several studies reported that out-level ROS over the threshold causes cell death or another type of permanent cell arrest as senescence (Ikawati et al., 2020; Larasati et al., 2018). The DCFDA staining, followed by flow cytometry analysis, was used to assess the level of ROS within cells caused by CCA-1.1. We employed doxorubicin as an ROS inducer in cells (Yokoyama et al., 2017). We noted a significant $(p<0.01)$ elevation of ROS level caused by concentrations of both CCA-1.1 and PGV-1 at a comparable level with doxorubicin (Fig. 6). These results are well consistent with the previous report and CCA-1.1 tends to have the same feature as PGV-1 in terms of ROS generation. In addition, these results also indicate that the increasing ROS level is correlated with senescence evidence and cell cycle arrest.

\section{DISCUSSION}

CCA-1.1 and PGV-1 have a similar structure backbone, but CCA-1.1 is superior due to its improvement of solubility in 


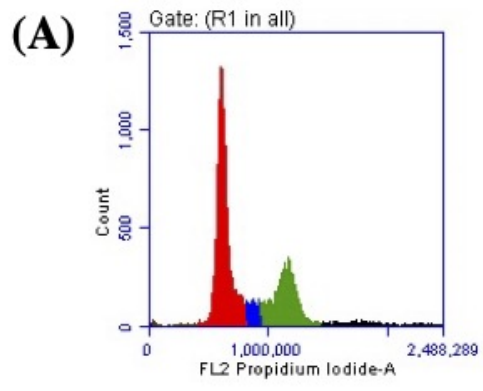

Untreated

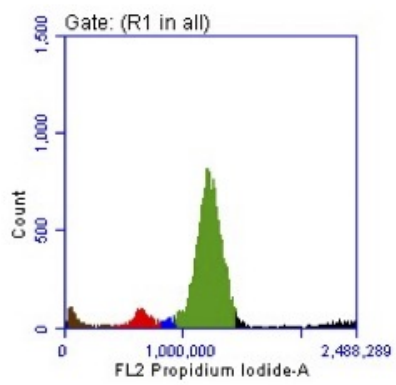

Dox 100 nM

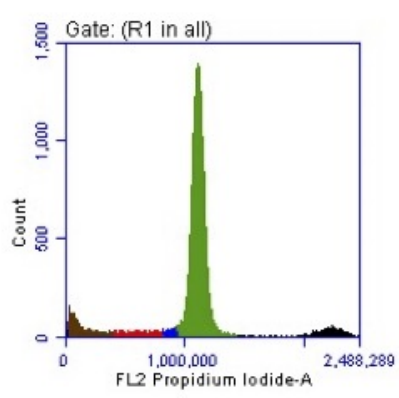

CCA-1.1 $2 \mu M$

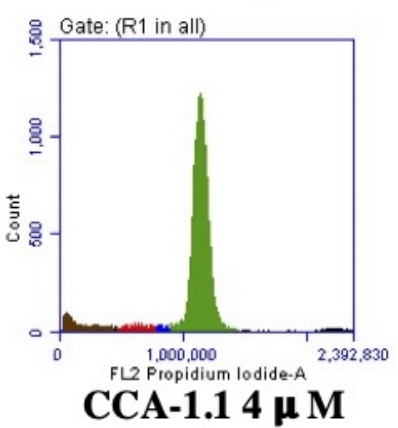

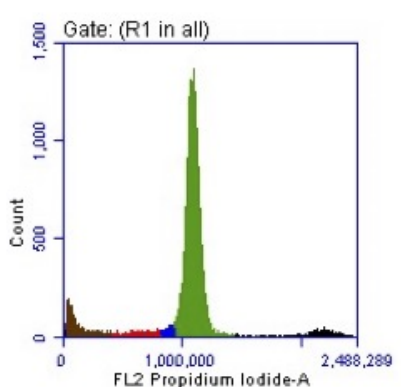

PGV-1 $2 \mu$ M

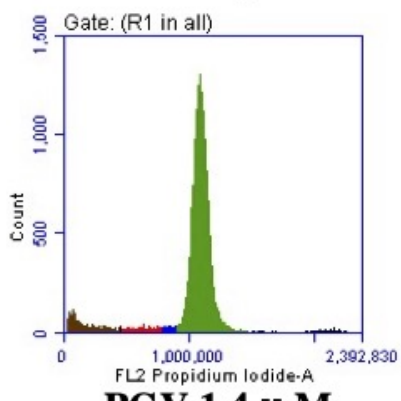

PGV-1 $4 \mu$ M

(B)

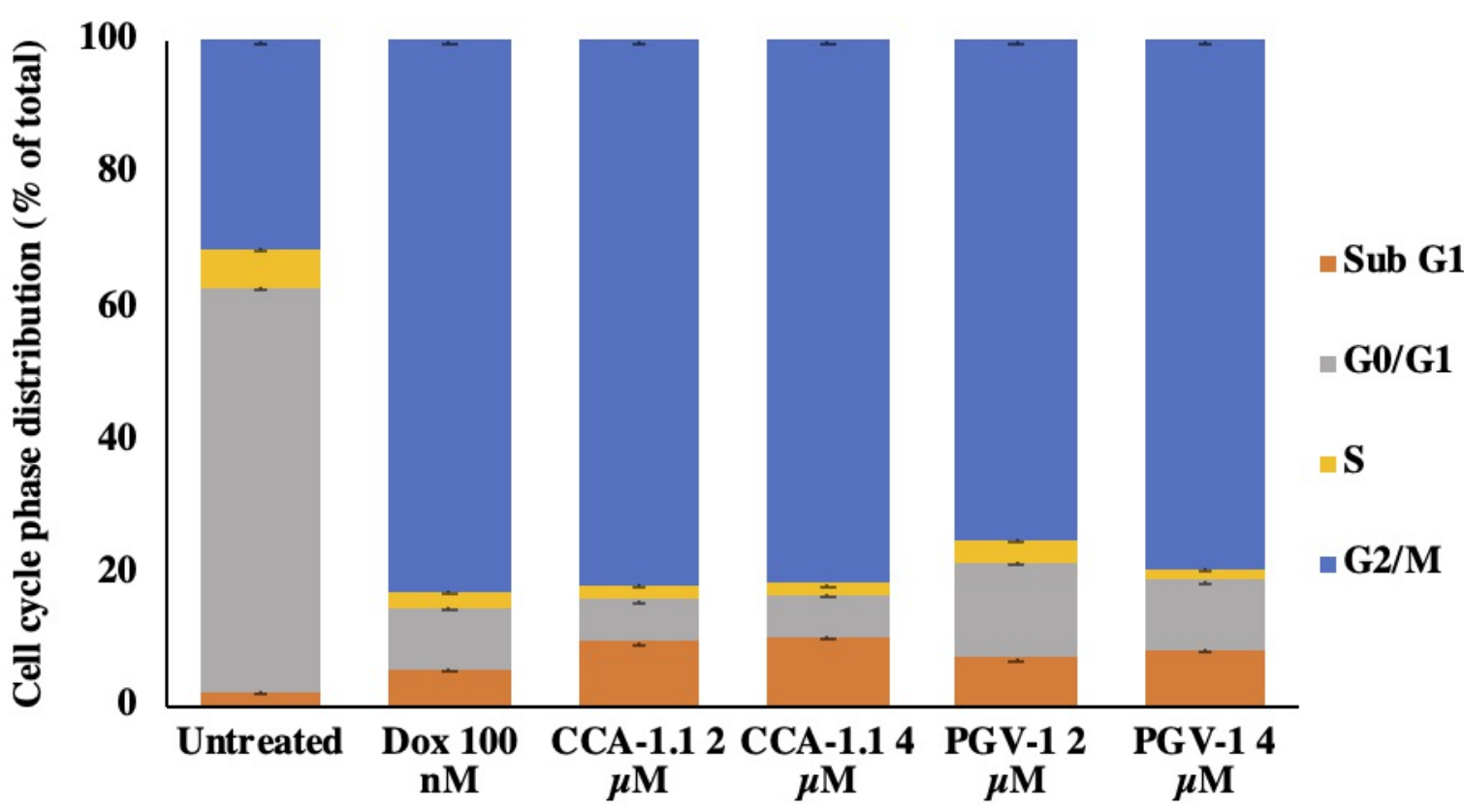

Figure 3. The modulation of cell cycle arrest on the treatment of CCA-1.1 and PGV-1 $(n=3)$. The cell cycle phase was determined by propidium iodide staining using a flow cytometer (A) as defined in the Materials and Methods section and the results are presented in a graph (mean $\pm \mathrm{SE}$ ).

aqueous solutions and stability, especially in an acidic environment, making it an auspicious candidate to combat PGV-1 as an anticancer candidate. Its stability in acidic solutions offers the possibility of CCA-1.1 to be developed as an oral anticancer drug. Additionally, CCA-1.1 had an equal or greater cytotoxicity on various types of cancer cells, including breast cancer cells (MCF-7/HER2, 4T1, MCF-7, HCC1954, and T47D), leukemia cells (K562), and colon cancer cells (Caco2 and WiDr) (Utomo et al., 2021). In this concern, we provided a piece of fundamental evidence through evaluating CCA-1.1's anticancer activities on WiDr cells to develop an effective candidate for colon cancer chemotherapy.

The current study disclosed the safety of CCA-1.1 on noncancerous NIH-3T3 (selectivity index $>10$ ) cells with greater toxicity on WiDr cells than PGV-1. These results give an insight that CCA-1.1 is possibly a safe agent to treat colon cancer cells. However, whether CCA-1.1 is safe for human consumption or not, such as 
(A)

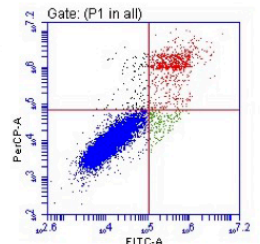

Untreated

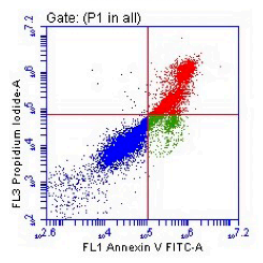

Dox $100 \mathrm{nM}$

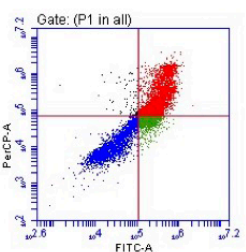

CCA-1.1 $2 \mu M$

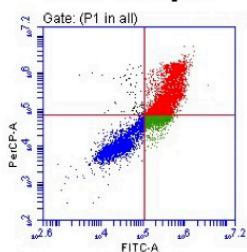

CCA-1.1 $4 \mu \mathrm{M}$

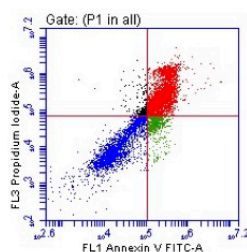

PGV-1 $2 \mu M$

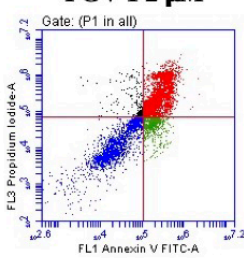

PGV-1 $4 \mu M$
(B

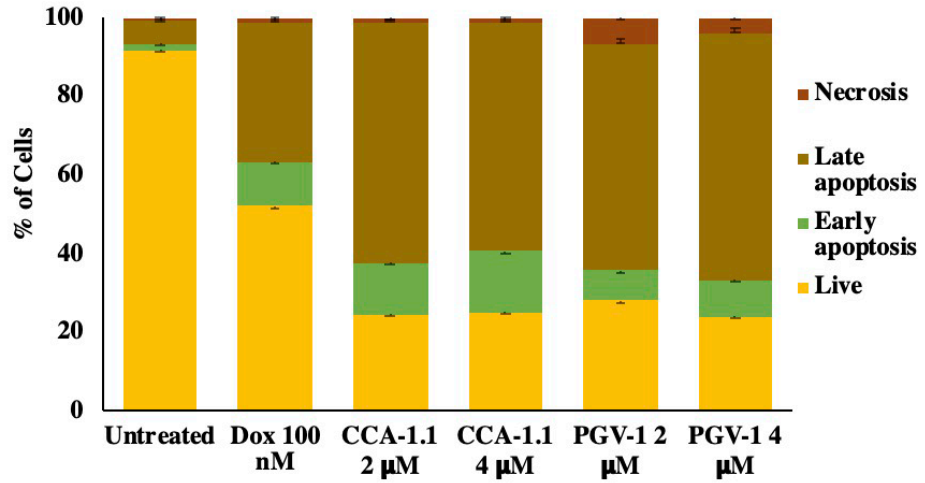

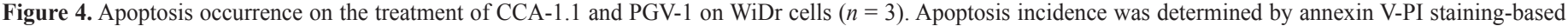
flow cytometry assay (A) and the $\%$ cell distribution was quantified into a graph (B) (mean \pm SE).

(A)
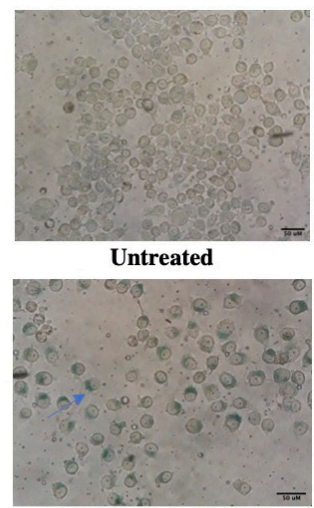

Dox $100 \mathrm{nM}$

$\longrightarrow$ Senescence cells

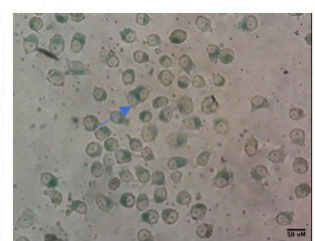

CCA-1.1 $2 \mu M$

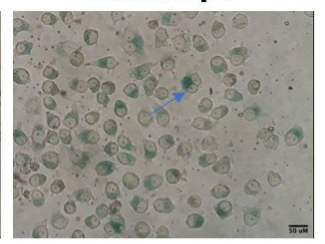

CCA-1.1 $4 \mu \mathrm{M}$

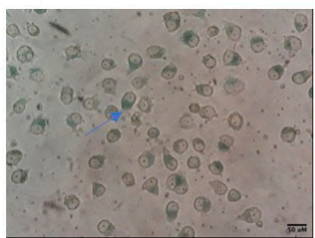

PGV-1 $2 \mu \mathrm{M}$

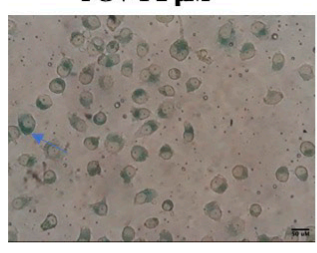

PGV-1 $4 \mu M$
(B) 100

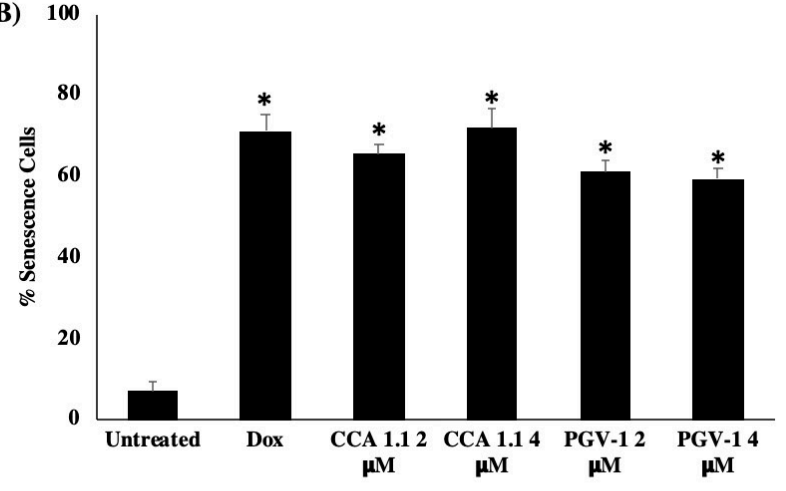

${ }^{*} \mathrm{p}$ value $<0,001$, compared to untreated group

Figure 5. Senescence incidence in WiDr cells $\left(2 \times 10^{5}\right.$ cells/well $\left./ \mathrm{ml}\right)$ on the treatment of CCA-1.1 and PGV-1 $(n=3)$. The morphology of senescence cells $(\mathrm{A})$ was observed under a microscope and its percentages were quantified into a graph (mean $\pm \mathrm{SE})$. Student's $t$-test was used to analyze the differences between treatments $\left({ }^{*} p\right.$ $<0.001)$.

(A)

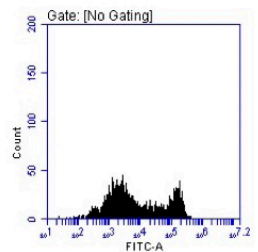

Untreated

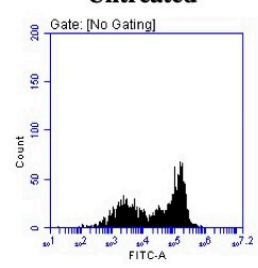

Dox 100 nM

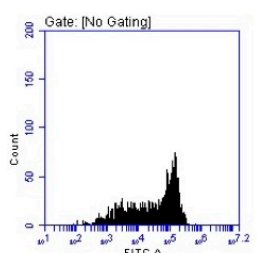

CCA-1.1 $2 \mu \mathrm{M}$

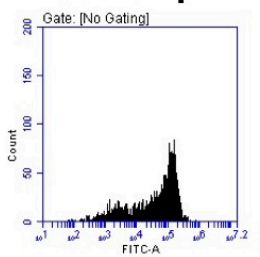

CCA-1.1 $4 \mu \mathrm{M}$

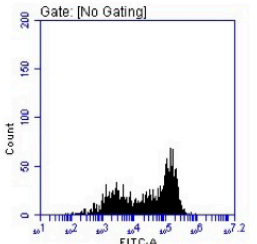

PGV-1 $2 \mu \mathrm{M}$

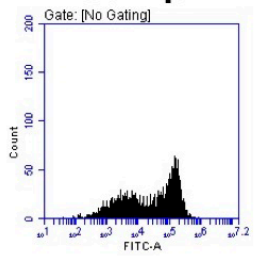

PGV-1 $4 \mu \mathrm{M}$
(B)

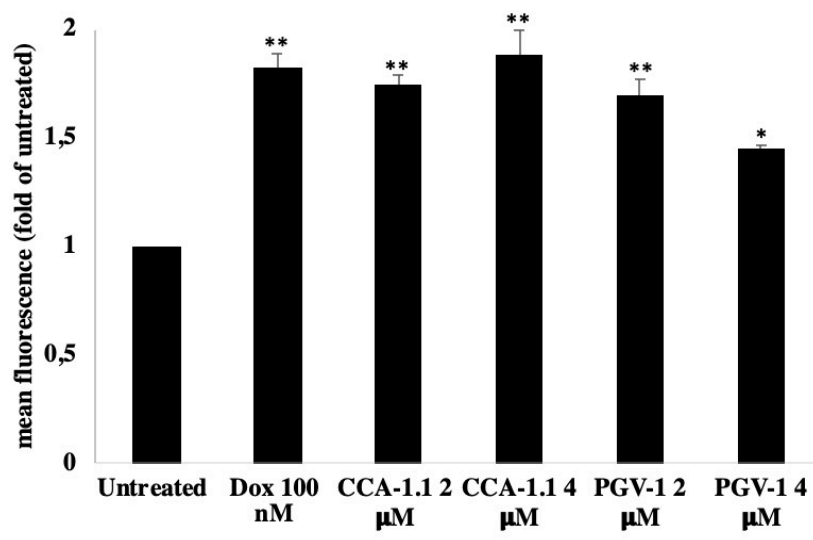

${ }^{*} \mathrm{p}$ value $<0,01 ;{ }^{*}$ p value $<0,001$, compared to untreated group

Figure 6. The level of intracellular ROS in WiDr cells on the treatment of PGV-1 and CCA-1.1 as defined in the Materials and Methods section ( $n=3$ ). DCFDA staining-based flow cytometry assay (A) was used to measure the ROS level and the results were presented as a graph (mean \pm SE). Student's $t$-test was used to analyze the variances between treatments $\left({ }^{*} p<0.01 ;{ }^{* *} p<0.01\right)$. 
curcumin (the lead compound) which is an ingredient in a healthy drink for people (Aggarwal and Harikumar, 2009), should be explored further. The cytotoxic effect of CCA-1.1 is more reliable than that of 5-FU on WiDr cells, as previously reported (Meiyanto et al., 2018). Even though 5-FU is a recommended drug for colon cancer therapy, it is described to raise the resistance of colon cancers and have serious side effects to patients (Goto et al., 2019), such as neuropathy, cardiotoxicity, and severe bone marrow suppression. Doxorubicin, paclitaxel, and cisplatin, often used as 5-FU substitutions, were also reported to have similar severe side effects (Florea and Büsselberg, 2011; Thorn et al., 2011). Despite the previous report that doxorubicin $\left(\mathrm{IC}_{50}: 1.6 \mu \mathrm{M}\right.$ ) is more potent than CCA-1.1 in WiDr cells (Wulandari et al., 2018), doxorubicin possesses disadvantages including poor solubility and instability under acidic conditions such as the gastric environment, which is not suitable for oral administration. Despite the incompatibility with its oral dosage form, doxorubicin seems to be the most suitable treatment preference since the oral route is comfortable, least invasive, and relatively nonexpensive for patients (Ahmad et al., 2018). A previous study stated that CCA-1.1 was stable in an acidic (gastric) environment, implying the possibility of oral use as a chemotherapy medicine. Since there are many colon cancer types with different attributes, further investigation of CCA-1.1's activities is required to evaluate the selectivity.

We noted an exciting result that CCA-1.1 mimics PGV1-inducing cell cycle arrest at the $\mathrm{G} 2 / \mathrm{M}$ phase, a complex and complicated stage in cell cycle progression (Rashidian et al., 2007). Lestari et al. (2019) reported that PGV-1 showed a unique inhibition of the cell cycle process at prometaphase on K562 cells (Lestari et al., 2019), which differs from curcumin that target anaphase (Lee and Langhans, 2012) and taxanes or vinca alkaloids that target microtubule spindles (Bates and Eastman, 2017). Defining the detailed targets of CCA-1.1 is an intriguing and challenging issue since the cell cycle elucidates various molecular pathways (Rashidian et al., 2007). Currently, targeting cell cycle regulators are ingenious advancements in cancer treatment (Kaldis and Richardson, 2012).

An arrest in cell cycle progression is intrinsically associated with senescence and apoptosis induction resulting in cell death in cancer cells (Foster, 2008). We presented PGV-1- and CCA-1-induced apoptosis at a similar level, and it is probably correlated with intracellular ROS elevation and senescence incidence. A balanced intracellular ROS level is needed to maintain cellular physiology and growth, especially in cancer cells. Cancer cells could undergo programmed cell death if the ROS level is higher than the threshold (Larasati et al., 2018). Consequently, a set of ROS metabolic enzymes in cancer cells is barely in charge to maintain an appropriate ROS level. At this point, the cytotoxic activity of PGV-1 is complemented by the initial-stage abrogation of several ROS metabolic enzymes (Lestari et al., 2019). Whether CCA-1.1 also mimics PGV-1 on elevating ROS levels by targeting ROS metabolic enzymes in cancer cells should be confirmed. Hence, the accumulation of ROS in cells has an opposite effect on cancer and healthy cells, where increasing ROS at an equal level in healthy cells can induce toxic possibilities in normal tissues and trigger side effects (Davalli et al., 2016). This was essential to explore since the increasing ROS level and senescence may appear in cancer cells and healthy cells.

Our data suggest that CCA-1.1 could be used instead of PGV-1, owing to its excellent aqueous solubility, which may be necessary for drug formulation. However, we have to note that this study was limited just to one kind of cell line, namely WiDr, a colon cell line with a particular molecular characteristic. We still need to examine this new compound against the other colon cell lines for a more comprehensive evaluation. Moreover, as the promising anticancer candidate for colon cancer, CCA-1.1 needs to be tested as a potential tumor-suppressing agent in animal models, including the safety evaluation and defining the molecular target's mechanism.

\section{CONCLUSION}

In conclusion, we determine that CCA-1.1 accomplished a greater cytotoxic effect than PGV-1 against WiDr cells with a comparable modulation on apoptosis and senescence, triggering arrest in cell cycle, and ROS elevation. Thus, promising features of CCA-1.1 are supported for developing an oral anticolon cancer drug. Some distinct potential target mechanisms have been documented for further exploration to gain a more comprehensive understanding of the anticancer mechanism of CCA-1.1.

\section{ACKNOWLEDGMENT}

The Ministry of Education and Culture, Indonesia, grant no. 3133/UN1.DITLIT/DIT-LIT/PT/2020, and the Center for Research and Development of Medicinal Plants and Traditional Medicine (B2P2TOOT), Tawangmangu, Karanganyar, Indonesia, have supported this study.

\section{AUTHORS' CONTRIBUTIONS}

Substantial contributions to the design and conception of the work: EM, MI, MK, and JK; acquisition of the data: FW; analysis and interpretation of data: FW, MI, JK, MK, and EM; drafting the work: FW, MI, and EM; revising the work critically: FW, MI, and EM; giving final approval of the manuscript: EM.

\section{ETHICAL APPROVAL}

This work does not involve subject experiments on animals or humans.

\section{CONFLICT OF INTEREST}

There are no conflicts of interest in this study.

\section{PUBLISHER'S NOTE}

This journal remains neutral with regard to jurisdictional claims in published institutional affiliation.

\section{REFERENCES}

Aggarwal BB, Harikumar KB. Potential therapeutic effects of curcumin, the anti-inflammatory agent, against neurodegenerative, cardiovascular, pulmonary, metabolic, autoimmune and neoplastic diseases. Int J Biochem Cell Bio, 2009; 41(1):40-59.

Ahlina FN, Nugraheni N, Salsabila IA, Haryanti S, Da'i M, Meiyanto E. Revealing the reversal effect of galangal (Alpinia galanga L.) extract against oxidative stress in metastatic breast cancer cells and normal fibroblast cells intended as a Co- chemotherapeutic and anti-ageing agent. Asian Pac J Cancer Prev, 2020; 21(1):107-17.

Ahmad N, Ahmad R, Alam MA, Ahmad FJ. Enhancement of oral bioavailability of doxorubicin through surface modified biodegradable polymeric nanoparticles. Chem Cent J, 2018; 12(1):65.

Aiello P, Sharghi M, Mansourkhani SM, Ardekan AP, Jouybari L, Daraei N, Peiro K, Mohamadian S, Rezaei M, Heidari M, Peluso I, Ghorat F, Bishayee A, Kooti W. Medicinal plants in the prevention and treatment of colon cancer. Oxid Med Cell Longev, 2019; 2019:2075614. 
Alessandrino F, Qin L, Cruz G, Sahu S, Rosenthal MH, Meyerhardt JA, Shinagare AB. 5-Fluorouracil induced liver toxicity in patients with colorectal cancer: role of computed tomography texture analysis as a potential biomarker. Abdom Radiol, 2019; 44:3099-106.

Bates D, Eastman A. Microtubule destabilising agents: far more than just antimitotic anticancer drugs: MDA mechanisms of action. $\mathrm{Br} \mathrm{J}$ Clin Pharmacol, 2017; 83(2):255-68.

Davalli P, Mitic T, Caporali A, Lauriola A, D'Arca D. ROS, Cell Senescence, and Novel Molecular Mechanisms in Aging and Age-Related Diseases. Oxid Med Cell Longev, 2016; 2016:3565127.

Ferlay J, Colombet M, Soerjomataram I, Mathers C, Parkin DM, Piñeros M, Znaor A, Bray F. Estimating the global cancer incidence and mortality in 2018: GLOBOCAN sources and methods. Int J Cancer, 2019; 144(8):1941-53.

Florea AM, Büsselberg D. Cisplatin as an anti-tumor drug: cellular mechanisms of activity, drug resistance and induced side effects. Cancers, 2011; 3(1):1351-71. 14(2):144-9.

Foster I. Cancer: a cell cycle defect. Radiography, 2008;

Goto K, Fujiwara Y, Isobe T, Chayahara N, Kiyota N, Mukohara T, Tsubata Y, Hotta T, Tamura K, Yamamoto N, Minami H. Pharmacokinetic study of the oral fluorouracil antitumor agent S-1 in patients with impaired renal function. Cancer Sci, 2019; 110(6):1987-94.

Handayani S, Susidarti RA, Jenie RI, Meiyanto E. Two Active Compounds from Caesalpinia sappan L. in Combination with Cisplatin Synergistically Induce Apoptosis and Cell Cycle Arrest on WiDr Cells. Adv Pharm Bull, 2017; 7(3):375-80.

Hermawan A, Fitriasari A, Junedi S, Ikawati M, Haryanti S, Widaryanti B, Da'I M, Meiyanto E. PGV-0 and PGV-1 increased apoptosis induction of doxorubicin on MCF-7 breast cancer cells. Pharmacon, 2011; 12(2):55-9.

Ikawati M, Jenie RI, Utomo RY, Amalina ND, Ilmawati GPN, Kawaichi M, Edy M. Genistein enhances cytotoxic and antimigratory activities of doxorubicin on 4T1 breast cancer cells through cell cycle arrest and ROS generation. J App Pharm Sci, 2020; 10(10):96-105.

Kaldis P, Richardson HE. When cell cycle meets development. Development, 2012; 139(2):225-30.

Kashyap D, Tuli HS, Sak K, Garg VK, Goel N, Punia S, Chaudhary A. Role of reactive oxygen species in cancer progression. Curr Pharmacol Rep, 2019; 5(2):79-86.

Kuilman T, Michaloglou C, Mooi WJ, Peeper DS. The essence of senescence. Genes Dev, 2010; 24(22):2463-79.

Larasati YA, Yoneda-Kato N, Nakamae I, Yokoyama T, Meiyanto E, Kato J. Curcumin targets multiple enzymes involved in the ROS metabolic pathway to suppress tumor cell growth. Sci Rep, 2018; $8(1): 1-13$

Lee SJ, Langhans SA. Anaphase-promoting complex/cyclosome protein $\mathrm{Cdc} 27$ is a target for curcumin-induced cell cycle arrest and apoptosis. BMC Cancer, 2012; 12(1):44.

Lestari B, Nakamae I, Yoneda-Kato N, Morimoto T, Kanaya S, Yokoyama T, Shionyu M, Shirai T, Meiyanto E, Kato JY. Pentagamavunon-1 (PGV-1) inhibits ROS metabolic enzymes and suppresses tumor cell growth by inducing $M$ phase (prometaphase) arrest and cell senescence. Sci Rep, 2019; 9(1): 14867

Li Q, Wang D, Li J, Chen P. Clinicopathological and prognostic significance of HER-2/neu and VEGF expression in colon carcinomas BMC Cancer, 2011; 11(277):1-6.

Meiyanto E, Putri DDP, Susidarti RA, Murwanti R, Sardjiman S, Fitriasari A, Husnaa U, Purnomo H, Kawaichi M. Curcumin and its analogues (PGV-0 and PGV-1) enhance sensitivity of resistant MCF-7 cells to doxorubicin through inhibition of HER2 and NF-kB activation. Asian Pac J Cancer Prev, 2014; 15(1):179-84.

Meiyanto E, Putri H, Larasati YA, Utomo RY, Jenie RI, Ikawati M, Lestari B, Yoneda-Kato N, Nakamae I, Kawaichi M, Kato JY. Anti-proliferative and anti-metastatic potential of curcumin analogue, pentagamavunon-1 (PGV-1), toward highly metastatic breast cancer cells in correlation with ROS generation. Adv Pharm Bull, 2019; 9(3):445-52.

Meiyanto E, Septisetyani EP, Larasati YA, Kawaichi M Curcumin analog pentagamavunon-1 (PGV-1) sensitizes Widr cells to 5-fluorouracil through inhibition of NF- $\mathrm{KB}$ activation. Asian Pac J Cancer Prev, 2018; 19(1):49-56.

Meiyanto E, Susidarti RA, Istighfari JR, Utomo RY, Novitasari D, Wulandari F, Kirihata M. Synthesis of new boron containing compound (CCB-2) based on curcumin structure and its cytotoxic effect against cancer cells. J App Pharm Sci, 2020; 10(2):60-6.

Novitasari D, Wulandari F, Jenie RI, Utomo RY, Kato JY, Meiyanto E. A new curcumin analog, CCA-1.1, induces cell cycle arrest and senescence toward ER-positive breast cancer cells. Int J Pharm Res, 2021; 13(1):9.

Panieri E, Santoro MM. ROS homeostasis and metabolism: a dangerous liason in cancer cells. Cell Death Dis, 2016; 7(6):e2253.

Rashidian J, Iyirhiaro GO, Park DS. Cell cycle machinery and stroke. Biochim Biophys Acta Mol Basis Dis, 2007; 1772(4):484-93.

Thorn CF, Oshiro C, Marsh S, Hernandez-Boussard T, McLeod $\mathrm{H}$, Klein TE, Altman RB. Doxorubicin pathways: pharmacodynamics and adverse effects. Pharmacogenet Genom, 2011; 21(7):440-6.

Utomo RY, Wulandari F, Novitasari D, Lestari B, Susidarti RA, Jenie RI, Kato JY, Sardjiman S, Meiyanto E. Preparation and cytotoxic evaluation of PGV-1 derivative, CCA-1.1, as a new curcumin analog with improved-physicochemical and pharmacological properties. Adv Pharm Bull, 2021; in press.

Wulandari F, Ikawati M, Meiyanto E, Kirihata M, Hermawan A. Bioinformatic analysis of CCA-1.1, a novel curcumin analog, uncovers furthermost noticeable target genes in colon cancer. Gene Rep, 2020; 21:100917.

Wulandari F, Ikawati M, Novitasari D, Kirihata M, Kato JY, Meiyanto E. New curcumin analog, CCA-1.1, synergistically improves the antiproliferative effect of doxorubicin against T47D breast cancer cells Indonesian J Pharm, 2021a; 31(04):244-56.

Wulandari F, Utomo RY, Novitasari D, Ikawati M, Kirihata M, Kato JY, Meiyanto E. The anti-migratory activity of a new curcumin analog, CCA-1.1, against T47D breast cancer cells. Int J Pharm Res, 2021b; 13(01):2877-87.

Wulandari N, Meiftasari A, Fadliyah H, Jenie RI. Red Betel Leaves Methanolic Extract (Piper crocatum Ruiz \& Pav.) Increases Cytotoxic Effect of Doxorubicin on WiDr Colon Cancer Cells through Apoptosis Induction. Indones J Cancer Chemoprevent, 2018; 9(1):1.

Yang MY, Lin PM, Liu YC, Hsiao HH, Yang WC, Hsu JF, Hsu $\mathrm{CM}$, Lin SF. Induction of cellular senescence by doxorubicin is associated with upregulated miR-375 and induction of autophagy in K562 cells. PLoS One, 2012; 7(5):e37205.

Yokoyama C, Sueyoshi Y, Ema M, Mori Y, Takaishi K, Hisatomi $\mathrm{H}$. Induction of oxidative stress by anticancer drugs in the presence and absence of cells. Oncol Lett, 2017; 14:6066-70.

How to cite this article:

Wulandari F, Ikawati M, Kirihata M, Kato JY, Meiyanto E. A new curcumin analog, CCA-1.1, induces cell death and cell cycle arrest in WiDr colon cancer cells via ROS generation. J Appl Pharm Sci, 2021; 11(10):099-105. 